ISSN 1678-3921

Journal homepage: www.embrapa.br/pab

For manuscript submission and journal contents, access: www.scielo.br/pab

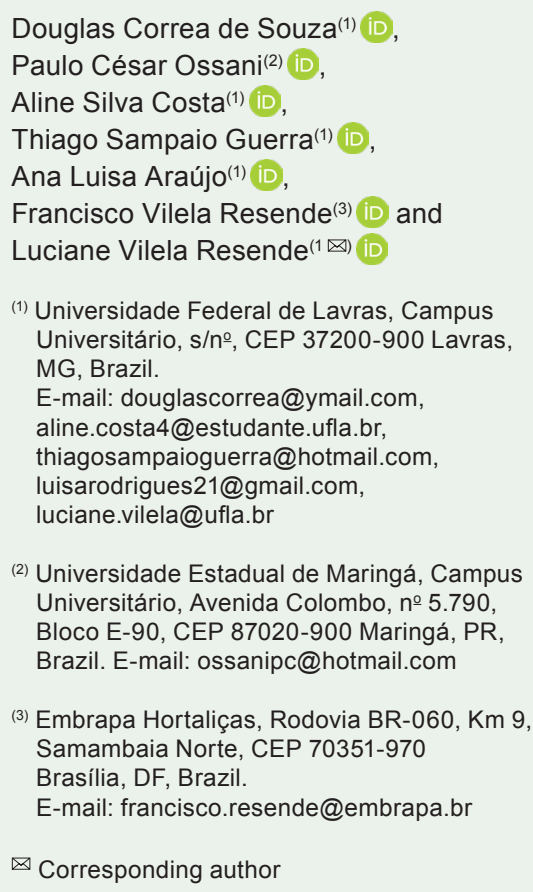

(2) Universidade Estadual de Maringá, Campus Universitário, Avenida Colombo, no 5.790, Bloco E-90, CEP 87020-900 Maringá, PR, Brazil. E-mail: ossanipc@hotmail.com

(3) Embrapa Hortaliças, Rodovia BR-060, Km 9, Samambaia Norte, CEP 70351-970 Brasília, DF, Brazil.

E-mail: francisco.resende@embrapa.br

$\bowtie$ Corresponding author

Received

May 13, 2021

Accepted

October 29, 2021

How to cite

SOUZA, D.C. de ; OSSANI, P.C.; COSTA, A.S.; GUERRA, T.S.; ARAÚJO, A.L.; RESENDE, F.V.; RESENDE, L.V. Selection of experimental strawberry clones for fruit appearance attributes. Pesquisa Agropecuária Brasileira, v.56, e02560, 2021. DOI: https://doi.org/10.1590/ S1678-3921.pab2021.v56.02560.

\section{Selection of experimental strawberry clones for fruit appearance attributes}

\begin{abstract}
The objective of this work was to carry out the morphological characterization of strawberry fruit of different genotypes, as well as to verify their postharvest conservation. Six commercial cultivars (Albion, Aromas, Dover, Festival, Pircinque, and San Andreas) and nine experimental clones (MDA01, MDA19, MDA22, MDA23, MCA89, MCA94, MFA443, MOGSC468, and MFA443PR) were evaluated. Fruit were produced on semihydroponic gutters in protected cultivation and classified according to size, shape, color, brightness, achene position, pulp color, "heart" color, fruit cavity, and sepal position. For the postharvest analysis of fruit, the loss of mass and the appearance of fruit during ten days of storage were determined. The evaluated genotypes show a high similarity to each other regarding morphological characterization. MCA89 and 'Pircinque' are the most divergent genotypes in relation to the others. There is an association between the characteristics large cavity, reniform shape, and medium cavity, which contributes to the indirect selection of desirable characters. On the tenth day of storage, the MDA01, MDA19, MCA89, MFA443, and 'Dover' genotypes still show acceptable conditions for commercialization.
\end{abstract}

Index terms: Fragaria x ananassa, exploratory analysis, plant breeding, post-harvest.

\section{Seleção de clones experimentais de morangueiro quanto aos atributos de aparência do fruto}

Resumo - O objetivo deste trabalho foi realizar a caracterização morfológica de frutos de morango de diferentes genótipos, assim como verificar sua conservação pós-colheita. Seis cultivares comerciais (Albion, Aromas, Dover, Festival, Pircinque e San Andreas) e nove clones experimentais (MDA01, MDA19, MDA22, MDA23, MCA89, MCA94, MFA443, MOGSC468 e MFA443PR) foram avaliados. Os frutos foram produzidos em bancadas semi-hidropônicas, em cultivo protegido, e classificados quanto a tamanho, formato, coloração, brilho, posição do aquênio, coloração da polpa, coloração do "coração", cavidade do fruto e posição das sépalas. Para a análise de póscolheita dos frutos, foram determinadas a perda de massa e a aparência dos frutos durante dez dias de armazenamento. Os genótipos avaliados apresentam alta similaridade entre si quanto à caracterização morfológica. MCA89 e 'Pircinque' são os genótipos mais divergentes em relação aos demais. Há uma associação entre as características cavidade grande, formato reniforme e cavidade média, o que contribui para a seleção indireta dos caracteres desejáveis. No décimo dia de armazenamento, os genótipos MDA01, MDA19, MCA89, MFA443 e 'Dover' ainda apresentam condições aceitáveis para comercialização.

Termos para indexação: Fragaria x ananassa, análise exploratória, melhoramento vegetal, pós-colheita. 


\section{Introduction}

Strawberry cultivation (Fragaria $\mathrm{x}$ ananassa Duch.) represents a consolidated activity in several regions in Brazil, with great socioeconomic impact, mainly in small areas with family farming (Gomes et al., 2013; Alves et al., 2020). This crop production is approximately 150,000 tons in $4,200 \mathrm{ha}$, with emphasis in the states of Minas Gerais, where production is 74,000 tons in 2,000 ha, Paraná (21,450 tons, 650 ha), and Rio Grande do Sul (20,350 tons, 550 ha) (Fagherazzi et al., 2017).

The species is highly valued due to its fresh commercialization and industrial processing. It is appreciated by consumers for its very well-defined sensory and nutritional characteristics (Guimarães et al., 2016). However, Brazilian producers have been faced with the high cost of crop production, due to the lack of national cultivars adapted to our edaphoclimatic conditions (Galvão et al., 2014; Vieira et al., 2017; Souza et al. 2019).

Attributes related to the appearance of the fruit should be taken into account in genetic breeding programs for the crop, as research has already shown that the appearance and color positively influence the flavor of the fruit (Maksimović et al., 2015; Tahir et al., 2018), in addition to the fact that, at the time of purchase, attributes such as color and appearance have a greater impact on the consumer than other characteristics, as they are the first to be evaluated (Fernández-Lara et al., 2015).

Another factor that should be observed is the postharvest time of the fruit, as it is a highly perishable product that undergoes a rapid loss of water in its tissues due to the high respiratory rate (Mirahmadi et al., 2011), in addition to being susceptible to the incidence of fungi which cause considerable nutritional and economic losses (Malgarim et al., 2006).

Considering the importance of developing a genotype that meets the needs of the producer, as well as those of the consumer market, the Universidade Federal de Lavras started a genetic breeding program aimed to obtaining materials adapted to the Brazilian edaphoclimatic conditions.

The objective of this work was to carry out the morphological characterization of strawberry fruit from the most promising genotypes of this breeding program, as well as to verify their postharvest conservation.

\section{Materials and Methods}

Fifteen strawberry genotypes from the genetic breeding program of the Universidade Federal de Lavras (UFLA) were evaluated - six commercial cultivars (Albion, Aromas, Dover, Festival, Pircinque, and San Andreas) and nine experimental clones (MDA01, MDA19, MDA22, MDA23, MCA89, MCA94, MFA443, MOGSC468 and MFA443PR) -, which were previously selected for their productive characteristics and fruit physicochemical quality (Souza et al., 2017, 2019; Vieira et al., 2017).

The experiment was carried out in the municipality of Lavras $\left(21^{\circ} 14^{\prime} \mathrm{S}, 45^{\circ} 00^{\prime} \mathrm{W}\right.$, at $918.8 \mathrm{~m}$ altitude), in the state of Minas Gerais, Brazil. The climate of the region, according to the climatic classification of Köppen-Geiger, is considered as subtropical highland climate, with dry winter and rainy summer (Alvares et al., 2013).

Strawberry fruit were produced in semi-hydroponic gutters in a protected cultivation conducted in randomized complete block design with three replicates, for the evaluation of agronomic performance of each genotype. Fertilization was performed in weekly fertigations with soluble salts, following the recommendations adapted from Ribeiro et al. (1999). Insecticide, fungicide, and herbicide were applied according to the needs of the crop.

For the morphological characterization, fruit were harvested weekly - in a total of 75 fruit per genotype [5 harvests x 5 fruit/harvest x 3 replicates (blocks)] -, on the following dates, in 2020: September 29, and October 07, 12, 19, and 26. Five random fruit from each experimental plot were selected and classified according to the morphological descriptors proposed by UPOV (2012) (Table 1). Each fruit was evaluated by three evaluators, totaling 225 evaluations for each genotype.

Exploratory data analysis was carried out in three stages. In the first stage, a descriptive analysis of the data was made, with basis on the frequency percentages of the event occurrences, and graphs were generated in accordance with UPOV (2012) to characterize the variables at their levels.

In the second stage, simple correspondence analysis was applied to establish the association between genotypes and categorical variables at their levels. The data for simple correspondence analysis constituted the occurrence frequency of the levels of categorical 
variables with 15 rows that characterized the studied genotypes, and 42 columns representing the variables in their levels (Table 1).

In the third step, the analysis was applied to establish the association between the variables at their levels by using the multiple correspondence analyses. This analysis showed 2,814 observations and 9 variables (Table 1).

Microsoft Excel software (Microsoft, 2019) was used in the first step of the analysis and, in the following steps, the results were obtained through the development of scripts in the R software ( $\mathrm{R}$ Core Team, 2020) for public use, through the MVar version 2.1.3 package (Ossani \& Cirillo, 2020).

For post-harvest conservation evaluations, the experiment was conducted in a completely randomized design, with three replicates of $100 \mathrm{~g}$ fruit of each genotype (about 10 strawberries). Fruit were harvested on September 14, 2020, packed in $154 \times 74 \times 57 \mathrm{~mm}$ polyethylene trays, and stored at $2.0 \pm 0.1^{\circ} \mathrm{C}$ in $\mathrm{BOD}$ for 10 days.

Evaluations for weight loss and fruit appearance were performed every two days, during 10 days of storage. Fruit were weighed for the weight loss determination on a precision scale (Zenebon et al., 2008), while fruit appearance was evaluated by a scale of scores gauged by two evaluators in accordance with Andrade Júnior et al. (2016). Appearance scores were attributed to fruit to meet marketing conditions, as

Table 1. Characteristics of strawberry fruit according to the morphological descriptors by UPOV (2012) and classified by notes.

\begin{tabular}{|c|c|}
\hline Characteristic & Description \\
\hline Size & 1-very small; 3-small; 5-medium; 7-large; 9-very large. \\
\hline Form & $\begin{array}{l}\text { 1-reniform; 3-conical; 5-cordiform; 7-ovoid; 9-cylindri- } \\
\text { cal; 11-rhomboid; } 13 \text {-obloid; 15-globular; 17-cuneiform. }\end{array}$ \\
\hline Color & $\begin{array}{l}\text { 1-whitish yellow; 3-light orange; 5-medium orange; } \\
\text { 7-orange red; 9-medium red; 11-dark red; 13-blackish } \\
\text { red. }\end{array}$ \\
\hline Brightness & 1-weak; 3-medium; 5 -strong. \\
\hline $\begin{array}{l}\text { Position of } \\
\text { the achenes }\end{array}$ & $\begin{array}{l}\text { 1-below the surface; } 3 \text {-at the same height as the surface; } \\
5 \text {-on top of the surface. }\end{array}$ \\
\hline Pulp color & $\begin{array}{l}\text { 1-whitish; 3-light pink; 5-orange red; 7-light red; 9-red } \\
\text { medium; } 11 \text {-dark red. }\end{array}$ \\
\hline "Heart" color & 1-white; 3-light red; 5-medium red. \\
\hline Cavity & 1. absent or small; 3-medium; 5-large. \\
\hline Sepals & 1-inserted; 3 -at the same height as the fruit; 5 -high. \\
\hline
\end{tabular}

follows: 3, good; 2 , reasonable; and 1, inadequate for marketing conditions.

Raw data of the evaluations were not transformed, due to the homogeneity between the replicates. The results were subjected to the analysis of variance, and the means were compared by the Scott-Knott's test, at $5 \%$ probability. For quantitative purposes, data were adjusted to a regression model with the aid of the $\mathrm{R}$ software (R Core Team, 2020).

\section{Results and Discussion}

The morphological characteristics - size, shape, brightness, cavity, color of the fruit, and pulp - were similar between the commercial cultivars and the experimental clones, as shown in the descriptive analysis (Figure 1).

At least $50 \%$ of the fruit showed sizes varying from medium to very large, mainly strawberry 'Albion' (84.44\%), followed by the experimental clones MCA89 (80.22\%), MDA19 (73.43\%) and strawberry 'San Andreas' (72.32\%). The Festival and Dover commercial cultivars had the lowest percentage of large fruit 40 and $49 \%$, respectively (Figure 1A). Regarding the format (Figure $1 \mathrm{~B}$ ), the genotypes showed a predominance of conical fruit, except for MCA89 that had $22.6 \%$ globular fruit, $18.64 \%$ of cylindrical fruit, $15.82 \%$ of obloid fruit, and the rest distributed among the other formats.

The color ranged from medium red to dark red with strong brightness, and small or absent cavity (Figure $1 \mathrm{C}$ ). Considering the pulp color, there was a predominance of red color; however the MDA22 clone showed $29.3 \%$ of fruit with whitish color.

As to the morphological characterization of the fruit, there was no significant genetic variability among the evaluated genotypes (Figure 2). However, variability was observed within the experimental genotypes and, to a lesser extent, within the cultivars that are already commercial, for most of the analyzed characteristics, evidencing the need for a more accurate selection process within the experimental clones.

In short, between the genotypes there was a predominance of conical shaped fruit, with strong brightness $(\geq 71.00)$ and absence of cavity $(\geq 92.00)$, external color and fruit pulp ranging from medium to dark red $(\geq 72,00$, and $\geq 71.00$, respectively), as well as high percentages of marketable fruit (medium, 


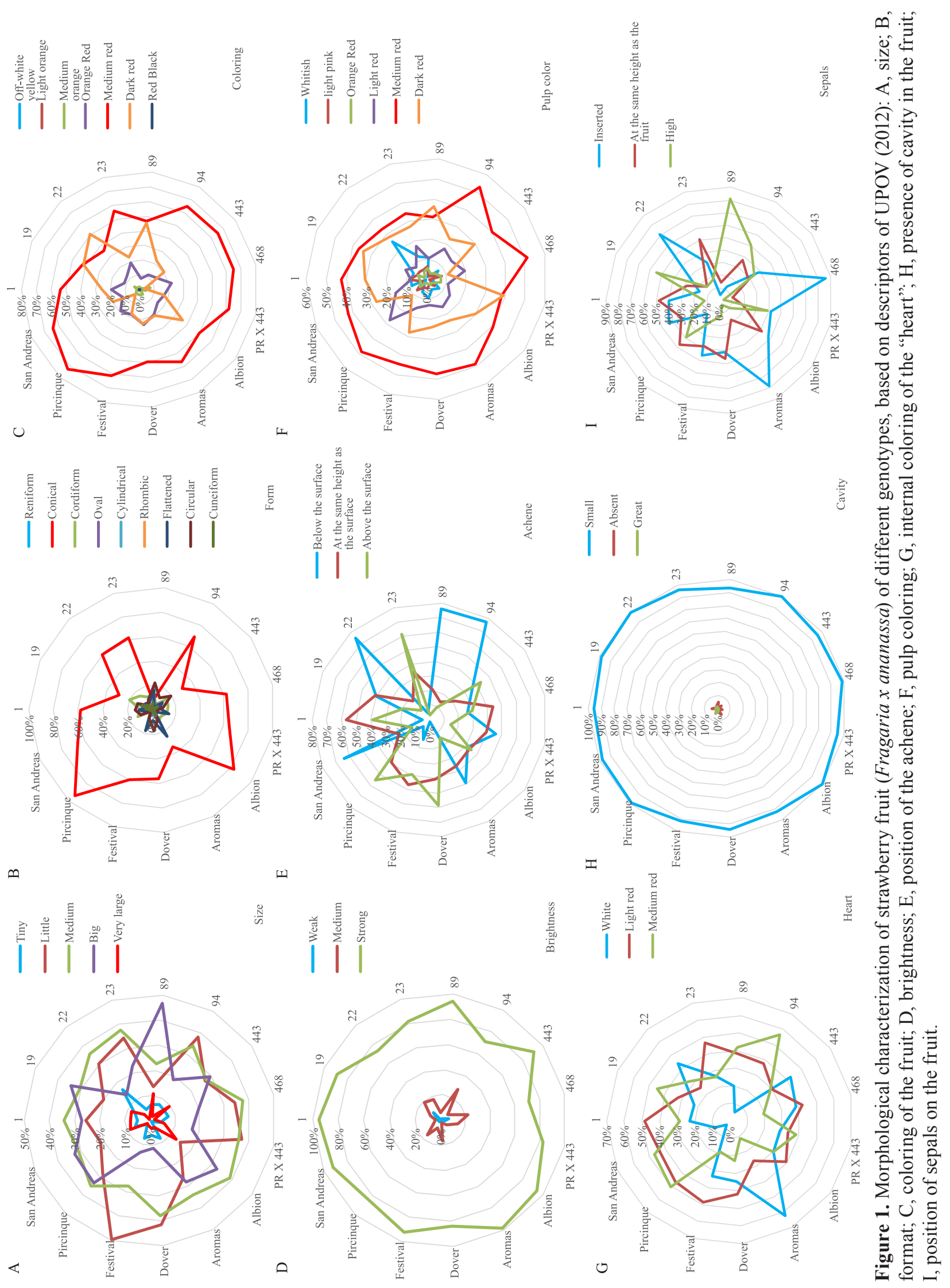


large, and very large sizes), except for the commercial cultivars Dover and Festival. MCA89 and 'Albion' stood out for their largest fruit sizes with $80.25 \%$ and $84.45 \%$, respectively, considering the attractive sizes for marketing. Size is the first characteristic of fruit appearance evaluated by consumers, at the time of product purchase, followed by general aspects such as bright red color, brightness, absence of pathogens, and fruit turgidity (Hasing et al., 2012; Zeist \& Resende, 2019).

In addition, the MCA89 genotype stood out for having some characteristics that set it apart from the others, such as an achene position below the surface, more intense pulp color (dark red), the position of the sepals above the fruit and most fruit in globular shape (Figure 2). It is noteworthy that in all previous stages of selection of this breeding program, this experimental clone has been highlighted by its high commercial standard (Galvão et al., 2017; Vieira et al., 2017; Souza et al., 2019).

In the graphical analysis (Figure 3), the coordinates of the points depict the chi-square distance projected on the corresponding axis (Silva, 2012). The chisquare test with 574 degrees of freedom and p-value: $1.0 \times 10^{-9}$, at $5 \%$ probability, indicated that there was dependence and, consequently, an association between the variables. The results of this association were explained in a two-dimensional space, which is established by the distances between the points that represent the genotypes (in red) and the points that represent the analyzed characteristics (in blue). Thus, the closer the characteristics are to the genotypes, the more associated they will be. The variation explained in the first two axes was $58.73 \%$ of the sample variation.

Characteristics of the genotypes show at least one of the morphological characteristics that differentiate it from the others (Figure 1).

In the results of the simple correspondence analyses performed between the 15 genotypes and traits, there was a high similarity between the evaluated genotypes for the characteristics analyzed, which confirmed by the point cloud concentrated in the center (Figure 3). These genotypes show common fruit characteristics such as conical fruit shape, bright red coloration and small cavity. However, genotypes that have distanced themselves from the origin are the least similar in comparison to the others (Figure 3).
The genotypes MDA22, MOGSC468, MDA19, MCA94, and MCA89, and 'Aromas' and 'Pircinque' distanced themselves from the center's genotypes, and among them, according to specific characteristics. Thus, the dark red color of the fruit (color 13) and the large size of the fruit (size 7) were strongly associated with MDA19. However, the clone MCA94 showed a strong association with large size (size 7) and medium red heart color (heart 5); similarly, 'Aromas' and MDA22 genotypes showed the greatest association with the number of very small fruit (size 1), whitish pulp color (pulp color 1), white heart color (heart 1) and inserted sepals (sepals 1); MOGSC468 distanced from the other genotypes because it was associated with the absence of fruit with large cavity (cavity 5), a greater amount of reniform fruit (form 1), and medium orange coloration (color 5), in relation to the other genotypes.

The characteristics that separated them were large fruit size and high sepal insertion (MDA19), globular shape of fruit, and dark red color of flesh (MCA89), high percentage of small fruit (MDA22), and higher percentage of red-orange fruit (MCA94). The clone MCA89 and the cultivar Pircinque were the most divergent in relation to the other evaluated genotypes. No genotype was associated with the characteristics that occupied the margins of the axes. The level of genetic similarity observed in the present study corroborates the findings by several authors (Morales et al., 2011; Gezan et al., 2017; Whitaker et al., 2020). These authors suggest that breeding programs use common parents, or parents. The sharing of genetic material among common ancestors in breeding programs can influence the genetic similarity between cultivars. In fact, in the present study, parents used to obtain hybrids have common ancestors.

The multiple correspondence analysis (MCA) could be represented in a two-dimensional space, since the first two components explained $41.43 \%$ of the sample variation (Figure 4). In general, a strong association is observed between the characteristics positioned in the center of origin in the graph. Characteristics such as large and medium cavity (cavity 5 and cavity 3) and reniform shape (form 1) showed a certain association and, given the distances of the points, these characteristics - together with those of red 

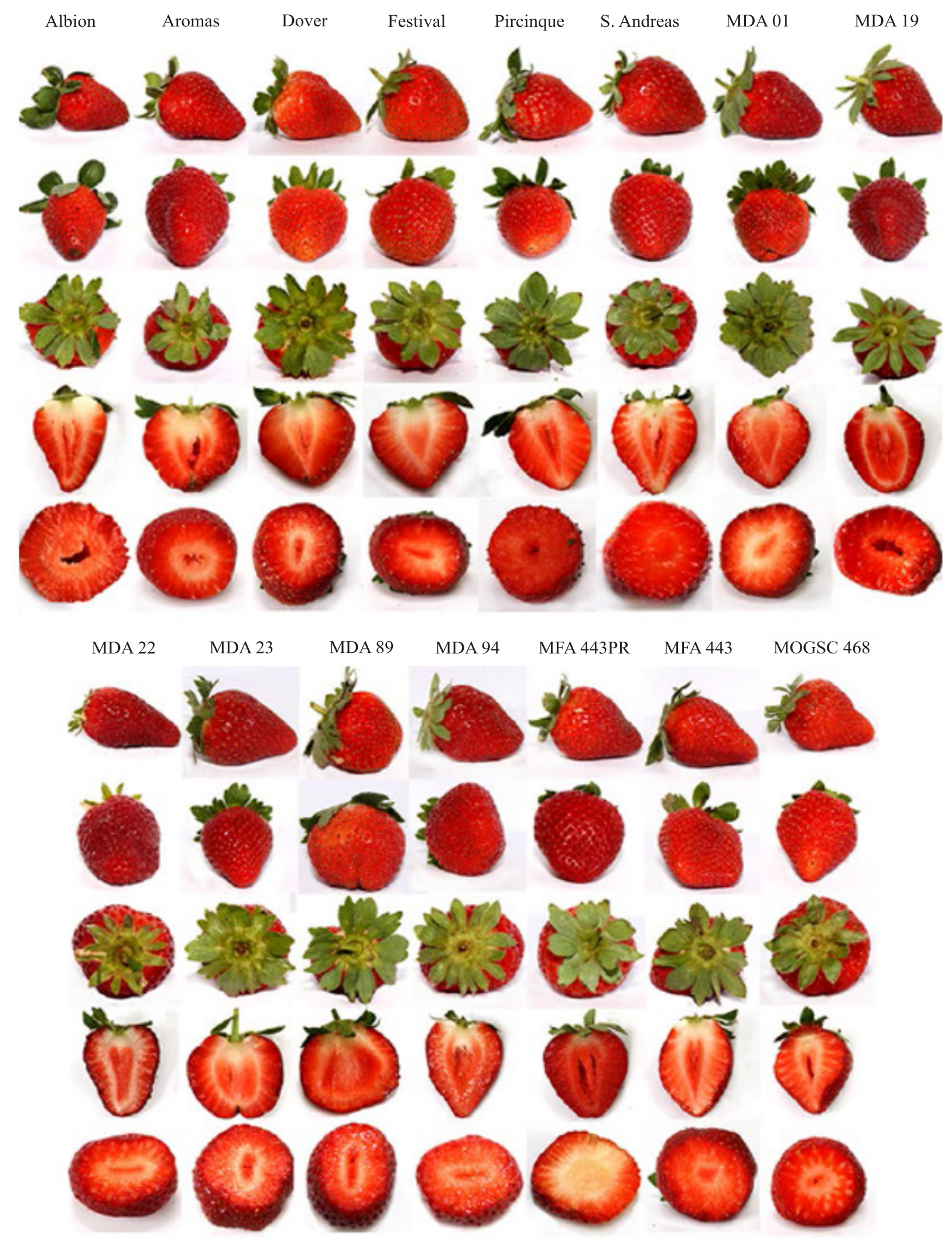

Figure 2. Morphological aspect of strawberry fruit from commercial cultivars and experimental clones of strawberry. 


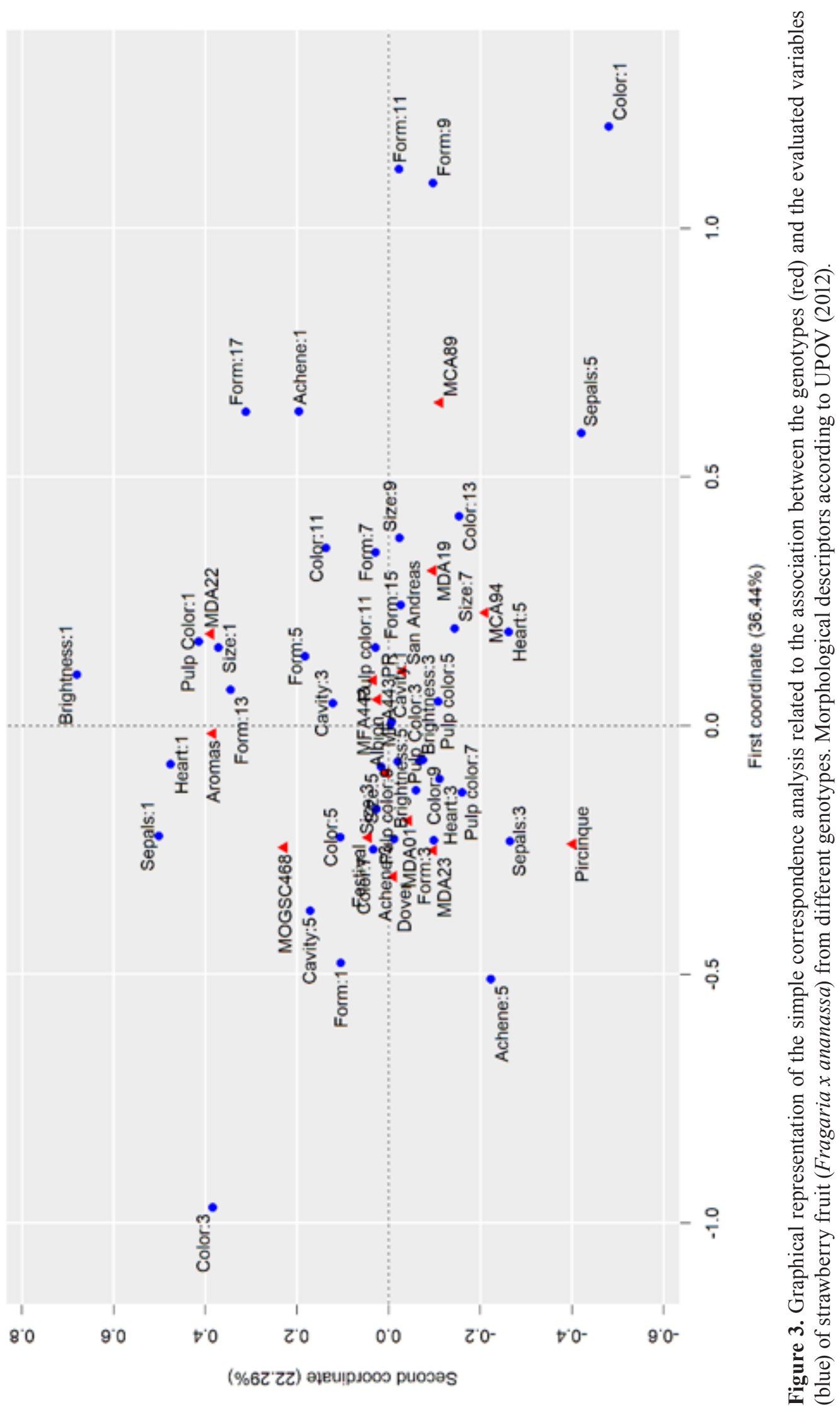




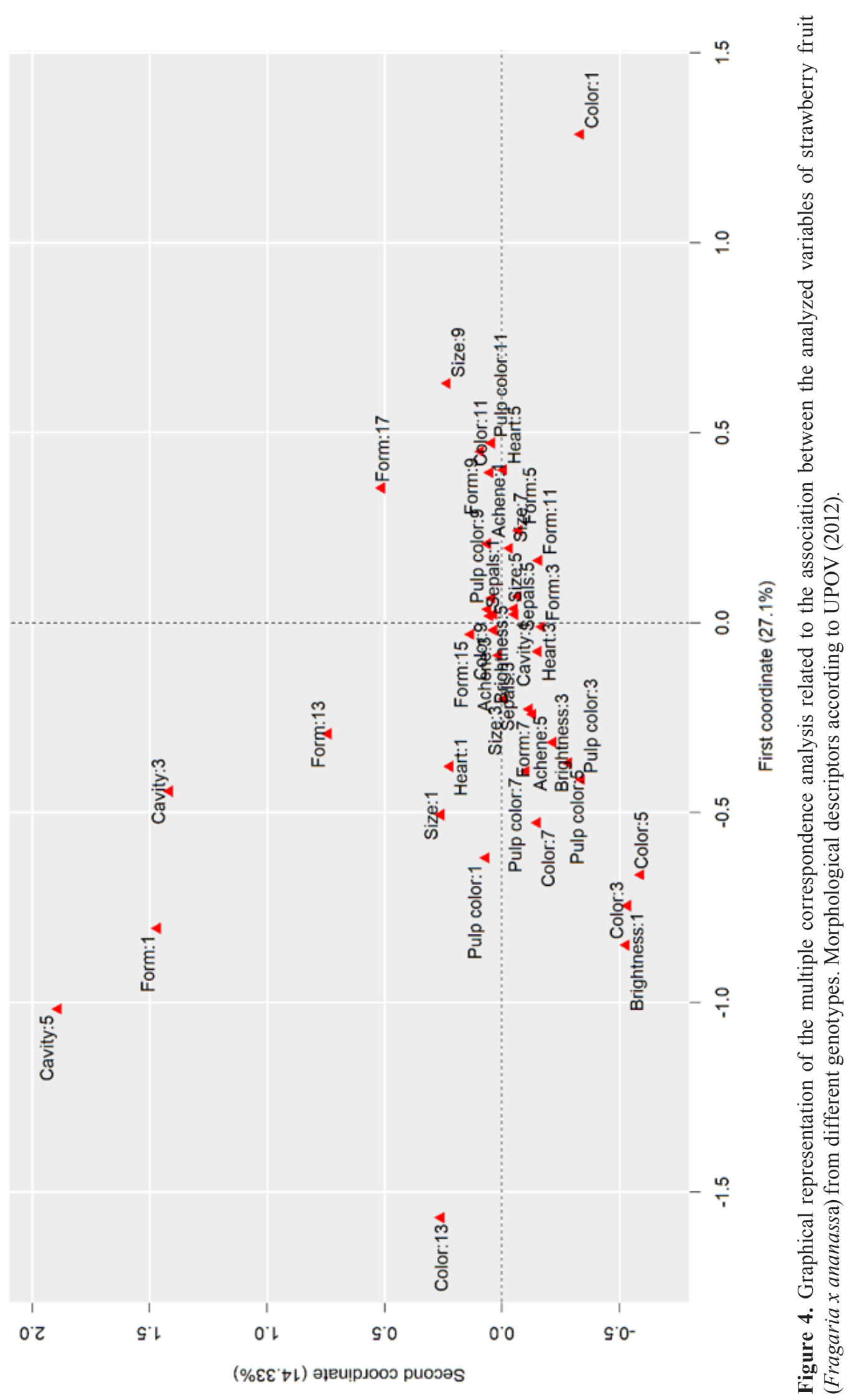


blackish (color 13) and whitish yellow (color 1) - were distinguished from the other characteristics.

The approximation of the points in the graph indicates that there is an association between some characteristics, which may allow indirect selection. There was a strong association between the external color of the fruit and the color of the pulp, as well as between the reniform shape and the presence of a cavity.

Contrary to what was observed in the present work, some authors reported that there is no genetic relationship between the internal and external color of the fruit (Hernanz et al., 2008), since these characteristics are governed by different sets of genes (Deng \& Davis, 2001). However, other authors observed that in addition to the genetic factor, the cultivation environment, and crop management impacts on the synthesis of anthocyanins show a direct relationship between the external and internal colors of fruit (Blancquaert et al., 2019).

In the present work, the association of simple and multiple correspondence analyses allowed to highlight the experimental clones MCA89 and MDA22 that have their own characteristics which, in turn, also stood out in other stages of the program for productive and chemical characters (Vieira et al., 2017; Souza et al., 2019). Meeting the high expectations of consumers is a challenge for breeders in the selection of genotypes based on appearance attributes (Zeist \& Resende, 2019).

The evaluated genotypes showed a similar behavior with each other for mass loss over the storage time of $5.60 \pm 1.0,67 \%$, except for the experimental genotype MDA23 and the cultivar Aromas that showed the greatest mass loss of mass over the storage period $14.57 \%$, and $16.78 \%$, respectively (Figure 5). From the sixth day onwards, a greater mass loss began to occur in all genotypes, and it was more accentuated in MCA89 and less accentuated in MFA443PR.

In the split between genotypes, throughout the evaluation for storage time and fruit appearance, fruit were showed good appearance with no variation between genotypes at the fourth day (Table 2). On the sixth day of storage, only the experimental genotypes MDA19, MFA443 and the commercial cultivar Festival received scores close to three, which did not differ statistically from the fourth day. Strawberry 'Dover' also received a score close to three, but began to differ statistically from the sixth day. On the tenth day of storage, only MDA01(1.83), MDA19 (2.0), MCA89 (2.0), MFA443 (2.0) and 'Dover' (2.17) showed reasonable appearance according to evaluators, since they received grades two or above.

Fruit weight loss is an important parameter to determine the useful life of fresh fruits and vegetables

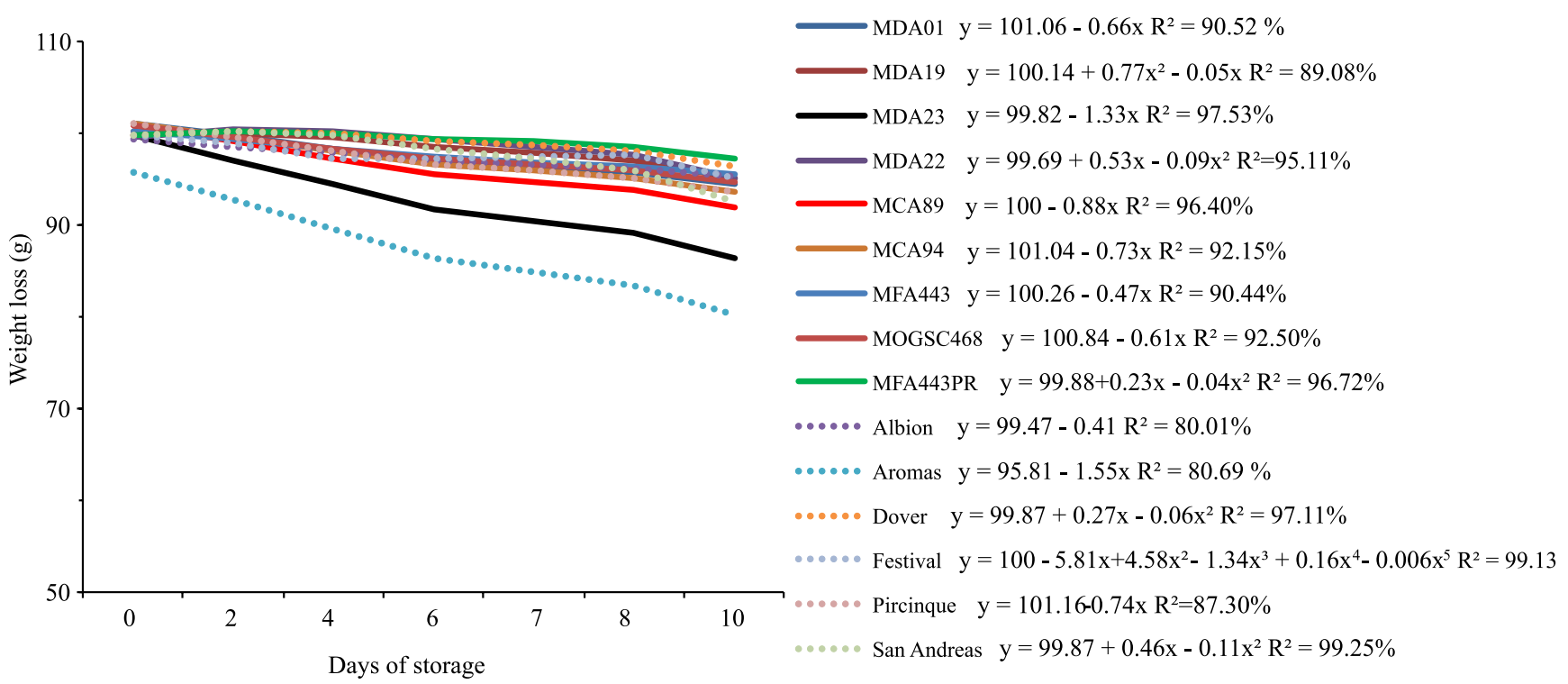

Figure 5. Loss of fruit mass of different strawberry genotypes (Fragaria x ananassa) during ten days of storage. 
Table 2. Average score related to the appearance of strawberry fruit (Fragaria $x$ ananassa) from different genotypes in relation to storage time ${ }^{(1)}$.

\begin{tabular}{|c|c|c|c|c|c|c|}
\hline \multirow[t]{2}{*}{ Genotype } & \multicolumn{6}{|c|}{ Storage days } \\
\hline & 0 & 2 & 4 & 6 & 8 & 10 \\
\hline MDA01 & $3.00 \mathrm{aA}$ & $3.00 \mathrm{aA}$ & $3.00 \mathrm{aA}$ & $2.33 \mathrm{bB}$ & $2.17 \mathrm{aB}$ & $1.83 \mathrm{aB}$ \\
\hline MDA19 & $3.00 \mathrm{aA}$ & $3.00 \mathrm{aA}$ & $3.00 \mathrm{aA}$ & $2.67 \mathrm{aA}$ & $2.33 \mathrm{aB}$ & $2.00 \mathrm{aB}$ \\
\hline MDA22 & $3.00 \mathrm{aA}$ & $3.00 \mathrm{aA}$ & $3.00 \mathrm{aA}$ & $2.17 \mathrm{bB}$ & $1.83 \mathrm{bB}$ & $1.00 \mathrm{cB}$ \\
\hline MDA23 & $3.00 \mathrm{aA}$ & $3.00 \mathrm{aA}$ & $3.00 \mathrm{aA}$ & $2.17 \mathrm{bB}$ & $1.67 \mathrm{bC}$ & $1.33 \mathrm{bC}$ \\
\hline MCA89 & $3.00 \mathrm{aA}$ & $3.00 \mathrm{aA}$ & $3.00 \mathrm{aA}$ & $2.33 \mathrm{bB}$ & $2.17 \mathrm{aB}$ & $2.00 \mathrm{aB}$ \\
\hline MCA94 & $3.00 \mathrm{aA}$ & $3.00 \mathrm{aA}$ & $3.00 \mathrm{aA}$ & $2.33 \mathrm{bB}$ & $1.83 \mathrm{bC}$ & $1.33 \mathrm{bD}$ \\
\hline MFA443 & $3.00 \mathrm{aA}$ & $3.00 \mathrm{aA}$ & $3.00 \mathrm{aA}$ & $2.67 \mathrm{aA}$ & $2.50 \mathrm{aB}$ & $2.00 \mathrm{aC}$ \\
\hline MOGSC468 & $3.00 \mathrm{aA}$ & $3.00 \mathrm{aA}$ & $3.00 \mathrm{aA}$ & $2.00 \mathrm{bB}$ & $1.67 \mathrm{bB}$ & $1.00 \mathrm{cC}$ \\
\hline MFA443PR & $3.00 \mathrm{aA}$ & $3.00 \mathrm{aA}$ & $3.00 \mathrm{aA}$ & $2.00 \mathrm{bB}$ & $1.67 \mathrm{bC}$ & $1.33 \mathrm{bC}$ \\
\hline Albion & $3.00 \mathrm{aA}$ & $3.00 \mathrm{aA}$ & $3.00 \mathrm{aA}$ & $2.67 \mathrm{bB}$ & $2.50 \mathrm{aB}$ & $1.83 \mathrm{aC}$ \\
\hline Aromas & $3.00 \mathrm{aA}$ & $3.00 \mathrm{aA}$ & $3.00 \mathrm{aA}$ & $2.33 \mathrm{bB}$ & $2.17 \mathrm{aB}$ & $1.33 \mathrm{bC}$ \\
\hline Dover & $3.00 \mathrm{aA}$ & $3.00 \mathrm{aA}$ & $3.00 \mathrm{aA}$ & $2.50 \mathrm{aB}$ & $2.33 \mathrm{aB}$ & $2.17 \mathrm{aB}$ \\
\hline Festival & $3.00 \mathrm{aA}$ & $3.00 \mathrm{aA}$ & $3.00 \mathrm{aA}$ & $2.67 \mathrm{aA}$ & $2.00 \mathrm{bB}$ & $1.67 \mathrm{aB}$ \\
\hline Pircinque & $3.00 \mathrm{aA}$ & $3.00 \mathrm{aA}$ & $3.00 \mathrm{aA}$ & $2.17 \mathrm{bB}$ & $1.83 \mathrm{bB}$ & $1.50 \mathrm{bC}$ \\
\hline San Andreas & $3.00 \mathrm{aA}$ & $3.00 \mathrm{aA}$ & $3.00 \mathrm{aA}$ & $2.33 \mathrm{bB}$ & $2.17 \mathrm{aB}$ & $1.50 \mathrm{bC}$ \\
\hline CV (\%) & \multicolumn{6}{|c|}{10.02} \\
\hline
\end{tabular}

because not only it is responsible for the deterioration of the visual appearance, but also for changes in texture, flavor, and nutritional value, therefore, it is an important factor in the definition of quality (Brasil \& Siddiqui, 2018).

In the present work, weight loss was $5.60 \pm 1.67 \%$ for most genotypes after ten days of storage. These results are in line with those obtained by other authors. The total weight loss of the harvest at the $7^{\text {th }}$ day of storage, analyzed in two consecutive years of the strawberry 'Festival', varied from $7.2 \%(90 \%$ $\mathrm{RH})$ to $19 \%(40 \% \mathrm{RH})$ in the first year, and from $5.7 \%(90 \% \mathrm{RH})$ to $15.5 \%(40 \% \mathrm{RH})$ in the second year (Ktenioudaki et al., 2019), and from 4.5\% for the 'Parous' (Hosseinifarahi et al., 2020). The latter author emphasizes that the loss of mass in strawberry fruit is due to high rates of respiration and perspiration because of this fruit does not have waxy substances in the outer skin. Several authors agree that the maximum mass loss that is commercially acceptable for strawberries should be lower than $6 \%$, before becoming unacceptable for commercialization (Brasil \& Siddiqui, 2018), and the loss of fresh weight above $10 \%$ is an indicator of loss of quality in strawberries (Mirahmadi et al., 2011), which causes the rejection of the fruit by consumers. In the present study, most of the genotypes showed a loss of mass of less than $6 \%$ during the entire storage period, except for MDA23 and 'Aromas'.

\section{Conclusions}

1. The evaluated genotypes show high similarity to one another for the morphological characterization.

2. The clone MCA89 and the cultivar Pircinque are the most divergent in comparison to the other evaluated genotypes.

3. There is an association between the characteristics large cavity, reniform shape, and medium cavity, which contributes for indirect selection of desirable characters.

4. On the tenth day of storage, the genotypes MDA01, MDA19, MCA89, MFA443 and 'Dover' still show acceptable conditions for marketing.

\section{Acknowledgments}

To Conselho Nacional de Desenvolvimento Científico e Tecnológico (CNPq) and to Fundação 
de Amparo à Pesquisa do Estado de Minas Gerais (Fapemig), for financial support; and to Coordenação de Aperfeiçoamento de Pessoal de Nível Superior (Capes, Finance Code 001), for granting scholarships.

\section{References}

ALVARES, C.A.; STAPE, J.L.; SENTELHAS, P.C.; GONÇALVES, J.L. de M.; SPAROVEK, G. Koppen's climate classification map for Brazil. Meteorologische Zeitschrift, v.22, p.711-728, 2013. DOI: https://doi.org/10.1127/09412948/2013/0507.

ALVES, M.C.; MATOSO, E.S.; PEIL, R.M.N. What is the profile of strawberry producers in the south Brazilian region and what do they think about substrate cultivation? Horticultura Brasileira, v.38, p.428-433, 2020. DOI: https://doi.org/10.1590/s01020536202004014 .

ANDRADE JÚNIOR, V.C.; GUIMARÃES, A.G.; AZEVEDO, A.M.; PINTO, N.A.V.D.; FERREIRA, M.A.M. Conservação póscolheita de frutos de morangueiro em diferentes condições de armazenamento. Horticultura Brasileira, v.34, p.405-411, 2016. DOI: https://doi.org/10.1590/S0102-05362016003016.

BLANCQUAERT, E.H.; OBERHOLSTER, A.; RICARDODA-SILVA, J.M.; DELOIRE, A.J. Effects of abiotic factors on phenolic compounds in the Grape Nerry - A review. South African Journal of Enology and Viticulture, v.40, 2019. DOI: https://doi.org/10.21548/40-1-3060.

BRASIL, I.M.; SIDDIQUI, M.W. Postharvest quality of fruits and vegetables: an overview. In: SIDDIQUI, M.W. (Ed.). Preharvest modulation of postharvest fruit and vegetable quality. London: Elsevier, 2018. p.1-40. DOI: https://doi.org/10.1016/B978-0-12809807-3.00001-9.

DENG, C.; DAVIS, T.M. Molecular identification of the yellow fruit color (c) locus in diploid strawberry: a candidate gene approach. Theoretical and Applied Genetics, v.103, p.316-322, 2001. DOI: https://doi.org/10.1007/s001220100648.

FAGHERAZZI, A.F.; GRIMALDI, F.; KRETZSCHMAR, A.A.; MOLINA, A.R.; GONÇALVES, M.A.; ANTUNES, L.E.C.; BARUZZI, G.; RUFATO, L. Strawberry production progress in Brazil. Acta Horticulturae, v.1156, p.937-940, 2017. DOI: https://doi.org/10.17660/ActaHortic.2017.1156.138.

FERNÁNDEZ-LARA， R.; GORDILLO, B.; RODRÍGUEZPULIDO, F.J.; GONZÁLEZ-MIRET, M.L.; DEL VILLARMARTÍNEZ, A.A.; DÁVILA-ORTIZ, G.; HEREDIA, F.J. Assessment of the differences in the phenolic composition and color characteristics of new strawberry (Fragaria $x$ ananassa Duch.) cultivars by HPLC-MS and imaging tristimulus colorimetry. Food Research International, v.76, p.645-653, 2015. DOI: https://doi.org/10.1016/j.foodres.2015.07.038.

GALVÃO, A.G.; RESENDE, L.V.; GUIMARAES, R.M.; FERRAZ, A.K.L.; MORALES, R.G.F.; MARODIN, J.C.; CATÃO, H.C.R.M. Overcoming strawberry achene dormancy for improved seedling production in breeding programs. Idesia, v.32, p.57-62, 2014. DOI: https://doi.org/10.4067/S0718-34292014000400007.
GALVÃO, A.G.; RESENDE, L.V.; MALUF, W.R.; RESENDE, J.T.V. de; FERRAZ, A.K.L.; MARODIN, J.C. Breeding new improved clones for strawberry production in Brazil. Acta Scientiarum. Agronomy, v.39, p.149-155, 2017. DOI: https://doi.org/10.4025/actasciagron.v39i2.30773.

GEZAN, S.A.; OSORIO, L.F.; VERMA, S.; WHITAKER, V.M. An experimental validation of genomic selection in octoploid strawberry. Horticulture Research, v.4, art.16070, 2017. DOI: https://doi.org/10.1038/hortres.2016.70.

GOMES, K.B.P.; OLIVEIRA, G.H.H.; CARVALHO, J.P.; CAVALCANTE, D.F. da S.; VILLA-REAL, M.E. Diagnóstico da cadeia produtiva do morango dos agricultores familiares do Distrito Federal. Revista Eixo, v.2, p.9-14, 2013. DOI: https://doi.org/10.19123/eixo.v2i2.110.

GUIMARÃES, A.G.; ANDRADE, J.V.C.; AZEVEDO, A.M.; GUEDES, T.J.; PINTO, N.A.V.D. Quality of strawberry grown in Brazilian tropical humid conditions for breeding programs. Fruits, v.71, p.151-160, 2016. DOI: https://doi.org/10.1051/ fruits/2016007.

HASING, T.; OSORIO, L.F.; WHITAKER, V.M. Estimation of genetic parameter and gains for color trats of strawberry. Euphytica, v.186, p.303-331, 2012. DOI: https://doi.org/10.1007/ s10681-011-0566-z.

HERNANZ, D.R.; RECAMALES, A.F.; MELÉNDEZMARTÍNEZ, A.J.; GONZÁLEZ-MIRET, M.L.; HEREDIA, F.J. Multivariate statistical analysis of the color-anthocyanin relationships in different soilless-grown strawberry genotypes. Journal of Agricultural and Food Chemistry, v.56, p.27352741, 2008. DOI: https://doi.org/10.1021/jf073389j.

HOSSEINIFARAHI, M.; JAMSHIDI, E.; AMIRI, S.; KAMYAB, F.; RADI, M. Quality, phenolic content, antioxidant activity, and the degradation kinetic of some quality parameters in strawberry fruit coated with salicylic acid and Aloe vera gel. Journal of Food Processing and Preservation, v.44, e14647, 2020. DOI: https://doi.org/10.1111/jfpp.14647.

KTENIOUDAKI, A.; O’DONNELL, C.P.; NUNES, M.C. do N. Modelling the biochemical and sensory changes of strawberries during storage under diverse relative humidity conditions. Postharvest Biology and Technology, v.154, p.148-158, 2019. DOI: https://doi.org/10.1016/j.postharvbio.2019.04.023.

MAKSIMOVIĆ, J.D.; POLEDICA, M.; MUTAVDŽIĆ, D.; MOJOVIĆ, M.; RADIVOJEVIĆ, D.; MILIVOJEVIĆ, J. Variation in nutritional quality and chemical composition of fresh strawberry fruit: combined effect of cultivar and storage. Plant Foods for Human Nutrition, v.70, p.77-84, 2015. DOI: https://doi.org/10.1007/s11130-014-0464-3.

MALGARIM, M.B.; CANTILLANO, R.F.F.; COUTINHO, E.F. Sistemas e condições de colheita e armazenamento na qualidade de morangos cv. Camarosa. Revista Brasileira de Fruticultura, v.28, p.185-189, 2006. DOI: https://doi.org/10.1590/S010029452006000200007.

MICROSOFT. Microsoft Excel. version 365. 2019. Available at: $<$ https://office.microsoft.com/excel>. Accessed on: Jan. 42021.

MIRAHMADI, F.; HANAFI, Q.M.; ALIZADEH, M.; MOHAMADI, H.; SARSAIFEE, M. Effect of low temperature 
on physico-chemical properties of different strawberry cultivars. African Journal of Food Science and Technology, v.2, p.109$115,2011$.

MORALES, R.G.F.; RESENDE, J.T.V. de; FARIA, M.V.; SILVA, P.R. da; FIGUEREDO, A.S.T.; CARMINATTI, R. Divergência genética em cultivares de morangueiro baseada em caracteres morfoagronômicos. Revista Ceres, v.58, p.323-329, 2011. DOI: https://doi.org/10.1590/S0034-737X2011000300012.

OSSANI, P.C.; CIRILLO, M.A. MVar: Multivariate analysis. R package version 2.1.3. 2020. Available at: $<$ https://cran.r-project. org/web/packages/MVar/>. Accessed on: Mar. 162021.

R CORE TEAM. R: a language and environment for statistical computing. Vienna: R Foundation for Statistical Computing, 2020. Available at: <http://www.R-project.org>. Accessed on: May 12 2020.

RIBEIRO, A.C.; GUIMARÃES, P.T.G.; ALVAREZ V., V.H. (Ed.). Recomendações para o uso de corretivos e fertilizantes em

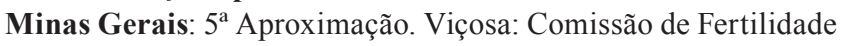
do Solo do Estado de Minas Gerais. 1999. 359p.

SILVA, Y.V. da. Análise de correspondência: uma abordagem geométrica. 2012. 140p. Dissertação (Mestrado) - Universidade Federal de Viçosa, Viçosa. Available at: <https://www.locus.ufv. br/bitstream/123456789/4058/1/texto\%20completo\%20.pdf $>$. Accessed on: Oct. 102021.

SOUZA D.C. de; OSSANI, P.C.; RESENDE, L.V.; CIRILLO, M.Â.; SILVA, L.F.L. e; XAVIER, J.B. Variabilidade genética entre cultivares comerciais e híbridos experimentais de morangueiro com ênfase em análise de múltiplos fatores. Magistra, v.30, p.4859, 2019.

SOUZA, D.C. de; VIEIRA, S.D.; RESENDE, L.V.; GALVÃO, A.G.; FERRAZ, A.K.L.; RESENDE, J.T.V. de; ELIAS, H.H. de S. Propriedades físico-químicas em frutos de híbridos experimentais de morangueiro. Agrotrópica, v.29, p.85-96, 2017. DOI: https://doi.org/10.21757/0103-3816.2017v29n1p85-96.
TAHIR, H.E.; XIAOBO, Z.; JIYONG, S.; MAHUNU, G.K.; ZHAI, X.; MARIOD, A.A. Quality and postharvest-shelf life of cold-stored strawberry fruit as affected by gum arabic (Acacia senegal) edible coating. Journal of Food Biochemistry, v.42, e12527, 2018. DOI: https://doi.org/10.1111/jfbc.12527.

UPOV. International Union for the Protection of New Varieties of Plants. Guidelines for the conduct of tests for distinctness, uniformity and stability: Strawberry: UPOV Code: Fraga: Fragaria L. Geneva, 2012. Available at: <https://www.upov.int/ edocs/tgdocs/en/tg022.pdf>. Accessed on: Oct. 12021.

VIEIRA, S.D.; SOUZA, D.C. de; MARTINS, I.A.; RIBEIRO, G.H.M.R.; RESENDE, L.V.; FERRAZ, A.K.L.; GALVÃO, A.G.; RESENDE, J.T.V. de. Selection of experimental strawberry (Fragaria $x$ ananassa) hybrids based on selection indices. Genetics and Molecular Research, v.16, gmr16019052, 2017. DOI: https://doi.org/10.4238/gmr16019052.

WHITAKER, V.M.; KNAPP, S.J.; HARDIGAN, M.A.; EDGER, P.P.; SLOVIN, J.P.; BASSIL, N.V.; HYTÖNEN, T.; MACKENZIE, K.K.; LEE, S.; JUNG, S.; MAIN, D.; BARBEY, C.R.; VERMA, S. Roadmap for research in octoploid strawberry. Horticulture Research, v.7, art.33, 2020. DOI: https://doi.org/10.1038/s41438020-0252-1.

ZEIST, A.R.; RESENDE, J.T.V. de. Strawberry breeding in Brazil: current momentum and perspectives. Horticultura Brasileira, v.37, p.7-16, 2019. DOI: https://doi.org/10.1590/S0102053620190101 .

ZENEBON, O.; PASCUET, N.S.; TIGLEA, P. (Coord.). Métodos físico-químicos para análise de alimentos. 4.ed., 1.ed. digital. São Paulo: Instituto Adolfo Lutz, 2008. 1020p. 